Journal of Siberian Federal University. Humanities \& Social Sciences 5 (2017 10) 673-684

\title{
Genesis of Non-generic Literary Forms \\ (Epitome - Essay - Blog)
}

\author{
Sergei A. Demchenkov* \\ Dostoevsky Omsk State University \\ 55a Mira, Omsk, 644077, Russia
}

Received 10.01.2017, received in revised form 03.03.2017, accepted 26.04.2017

\begin{abstract}
The concept of non-generic literary forms has become part of literary studies quite recently. It refers to the phenomena, which can not be satisfactorily described as part of the canonical Aristotelian triad "Epic, Lyrics, Drama". The paper provides a novel approach to understanding the non-generic literary forms in phenomenological and existential terms. This makes it possible to identify the main stages of their formation and characterize their specificity defined by the possibility of objectifying of a living personal being of a subject in the text. The epitome genre marks the initial stage of formation of non-generic forms: It postulates a writer's fundamental rejection of artistic fiction. The main objective of the essay is to acquaint the author and the recipient with a genuine (though impersonal) being through writing. Essay is not so much an artistic creativity as an existential creativity. It is a continuation of its immediate living being in writing. Blog serves a similar function. However, unlike essay, it is not a one-time existential act, rather a continual existential self-fulfillment through writing, notably on the part of both the author and the recipients. The analysis done allows us to reason that the genres of interest relate to the three successive stages of forming a new paradigm of verbal creativity. The classic paradigm involves the artistic creation of a fictional reality with an imaginary, though self-sufficient being, and despite its deliberate affectation is often perceived as more live and authentic than reality given to us in sensation. In the period from the mid. $1900 \mathrm{~s}$ to beg. $2000 \mathrm{~s}$, we have consistently observed a growing opposite trend: desire to eliminate an irresistible "being in the art/being in reality" dichotomy as part of the classical model. In essay studies and, particularly, blogosphere, the verbal and artistic creativity aims not at creating virtual "worlds", rather at the existential formation of an individual in social and natural reality through writing.
\end{abstract}

Keywords: literary genre, non-generic literary forms, epitome, essay, essayism, blog, diary, existence.

DOI: 10.17516/1997-1370-0075.

Research area: philology.

The category of intergeneric (two-generic) literary formations which involve the features of two literary genres is a common knowledge today. The term "non-generic forms" has not yet been fixed in the literary studies. "Encyclopedia of Literature" which resumes the achievements made by the national literary studies in the latter half of the $20^{\text {th }}$ century says only about intergeneric phenomena and general tendency to the genre-and-form syncretism peculiar to the modern art and most vividly reflected in the stream of consciousness (Epshtein, 1987: 329).

(C) Siberian Federal University. All rights reserved

* Corresponding author E-mail address: omgu5555@gmail.com 
Justifying the notion of non-generic forms V.Ye. Khalizev in his book on the theory of literature summarizes with some shade of uncertainty: "Indeed, the literature includes such groups of works which cannot be related to epos, lyrics or drama to the full extent, or even as much as be excluded. In a regular manner, they should be considered as non-generic forms" (Khalizev, 1999: 317). According to the author, such diffusive phenomena alongside with the stream of consciousness may include epitome and essay.

The analysis of educational materials on the introduction to literary studies and the theory of literature reflected in the web-sites of Russian universities demonstrates that V.Ye. Khalizev's idea has largely been supported by the experts: the notion of non-generic forms is often included into exams for the students and post-graduate students of philology who take the qualifying exam of "Russian Literature" and "Literary Theory".

Despite a widespread performance, the term has not yet been recognized as a canonic one. It is notable that "Encyclopedia of Literary Terms and Notions" published in 2001, as well as "Encyclopedia of Literature", even in their entry "Literary form" do not resort to this category (Tamarchenko, 2001: 882). Within this context, epitome is defined traditionally, i.e. as an epic genre (Gordeeva, 2001: 707); the problem on generic assignment of the essay and stream of consciousness literature is not addressed (Zverev, 2001: 773; Murav'ev, 2001).

A hampered membership of "non-generic forms" in the literary studies is caused not only by a natural inertia of the scientific thought, but also by the backup of the long-present subsumption ideas in the literary-theoretic studies within the $20^{\text {th }}$ and $21^{\text {st }}$ centuries.

It has been said that the nature of nongeneric forms is determined, on the one hand, by a blandness of the "model" characteristics peculiar to one of Aristotelian's genres, on the other - by the possibility to easily combine the features of all three literary forms, e.g. the epitome can be not only epic, but also lyrico-epic and lyrico-dramatic nature; the same is true for the essay as well.

Thus, the genre's borders have not been shaped by the borders of form any more. As often as it is required such genres as epitome and essay can be resourced through any of the literary forms in any proportion desirable for the author.

To prove the fact that this point of view has been settled in "ordinary" literary consciousness, let's refer to a pretty specific resource - "Otvety Mail.ru" - the users of which can get answers on any question from other web-guests:

"- Please, explain to me, a silly-billy, on what grounds an epitome, essay and stream of consciousness literature are concerned as nongeneric forms. I've already looked up and down everything, but nothing so much insightful? What's the thing?

- Because they cannot be related neither to drama, lyrics or epos. The literature knows only three forms. These genres include certain elements of all the literary forms and bear their own identity at the same time. This is the ground" (Otvety Mail.ru).

\section{Statement of the problem}

In our observation, the non-generic essence of essays and epitomes is explained not by their middle position between the elements of Aristotelian trine, but by their principal noncorrelation with the category of literary form, i.e. with that "carcass" of the classic literary paradigm. In other words, their nature is caused not by a specific status inside the current paradigm, but their non-paradigmality.

Shrinking away from detailed thorough descriptions, we focus on a solely crucial paradigm characteristic which is likely to 
be the most significant in the context of our discussion.

In a varying degree, under the classic paradigm the art creation acts like the worldcreation. Through the artistic devices the author creates a conventional reality, mimetically linked to the natural environment and social life around us, but, nevertheless, characterized by an autonomous genesis - a simulated one, but immortal at the same time.

The text substance is comprehended both by the reader and author as a priori illusory, which, in turn, appears to be more convincing, more evident, and finally more reality-strong rather than our own earthy life. Shall we remember a distich by A. Fet who so much lapidary resumed this paradox: «Этот листок, что иссох и свалился, / Золотом вечным горит в песнопеньи».

A steadily rooting in the cultural consciousness contrast between extremity/ imperfection of our private life and the perfection of an absolute genesis of our reflections in the artistic foreign reality generates a whole spectrum of interrelated effects.

Firstly, a problem of correlation between the art and reality discussed by different artists of different times is considered as a fundamental issue.

Secondly, they establish and address in details such idea of the art to be the higher form of the human genesis; to be a new sacrality eligible for replacing those religious and sacral beliefs about extra-genesis and extra-reality.

Thirdly, as far as the classic paradigm is being developed, there is an implicit growth of irrational experience on "existential envy" in the culture. The art which indirectly, but, at the same time, highly insistently declare a fullperformance of an illusive and virtual genesisin-the-text set against an imperfect genesis-inreality, provokes a natural reaction of rejection and an active search for new types of creation inside which that fundamental dichotomy "art/ reality" is likely to be overcome.

Such genres as epitome, essay and blog which presumably can be included into the list of non-generic forms come out under the classic paradigm, but mark some primary stages in a consistent evolution of a brand-new literary paradigm entering with its ancestress into competitive relations.

Applying to the framework of general and phenomenological ontology in this case is reasonable. To comprehend the nature of non-generic forms, and mainly, of those iconic cultural processes in which they are considered as the results, is extremely problematic unless we use only aesthetic categories per se.

To justify such statement we refer to the work by V. Aristov, who, addressing the problem of essay's genre specificity, assumes the concept of "ontological proto-changes" in the literary forms and genres (Aristov, 2010).

\section{Methods}

Analyzing the origin of literary forms, the ways of development in this or that literary tradition, the scientists, as a rule, rely on comparative methods in the literary studies. Such approach is, undoubtedly, efficient in the context when the research has, in general, a retrospective character and focuses on completed phenomena.

In case the research has a forward-looking orientation and a certain number of phenomena is analyzed through the angle of global tendencies in the literary development which have yet been selectively and fragmentarily discovered in the empirical basis, there is a necessity to add the comparative device with an all-philosophical methodology.

Further we will consider the literary forms mainly from the perspective of their existential character, using both the comparative and phenomenological analysis. 
It is worthy to note that in this case the question is not about the literary futurology (i.e. attempts to foresee something not existing in the reality), but about how to reveal those nonbiased tendencies represented within the steadily development of the literary genres, but, indeed, projected onto the future.

\section{Discussion. Epitome: an introduction to the genesis}

In the framework of essayistics the written literature makes its faint attempts to "break" the classic paradigm from the inside. The term "epitome" nominates a wide range of phenomena - from describing manners notes in the beginning of the $18^{\text {th }}$ century to a canonical "The Hunting Sketches" and modern practice in newspapers and journalism.

However, such variety of different literary findings classified into numerous sub-genres of epitome has a common vector: in a pointed manner they are keen on asserting themselves as a literature of authenticity, directly or indirectly separating from the literature of fiction.

The subject of an artistic exploration of the epitome is the life per se in its richest and most remarkable manifestations. The author acts only as a "medium" between the recipient and reality. They live it through all their senses and, probably, emotions and mind as well, but not through their imagination. Similar to the religious visionists, they show through themselves something immeasurably greater and more important, than they are; in an honest manner they capture everything that has been seen and heard even if they don't fully understand its meaning.

In this sense, a parallel to the prophets is no accident here: the epitome's author can evaluate, comment and analyze those phenomena which they witness, but they should strongly reject inventing or reinterpreting of the proto-basis, i.e. that "genesis revelation" which they tackle to bring for the reader in a state of its nature.
To reiterate, we are interested in a "model" epitome, or, more precisely, in its "genre vector" with different degrees of success represented in particular invariants of the genre pattern.

Thus, the epitome states a basic freedom from the cornerstone of the classic literary paradigm, i.e. artistic fiction. Instead of entering into "imaginary" worlds (even more real than the reality per se, thanks to the genius of its creator), it offers involvement into the life. However, such performance has a passive form, i.e. through contemplation and reflection.

\section{Essay as an existential type of writing}

As it is known, the origin of essayistics is dated between the end of $16^{\text {th }}$ and the beginning of the $17^{\text {th }}$ centuries ("Essays" by M. Montaigne and "Essays" by F. Bacon). Nevertheless, given the traditional and not the chorological background, the essay represents the next step on the way to "overcome" the classic literary paradigm in comparison with the epitome.

In schools of journalism students are taught to write essays; an extra attention is paid to the genre requirements. However, such texts cannot be regarded as essayistic per se. A true essay does not accept any norms or requirements at all.

According to M.N. Epshtein, the essay is a neutral genre which "only relies on its non-genre nature"; "the essay keeps its character only in the case when constantly crosses the framework of other genres, encouraged by the spirit of wandering, by the desire to taste everything, but not be engaged" (Epshtein, 1982).

Still, even this point is not a crucial one.

The essay is not solely a genre beyond the genre, but it also a special type of writing. There is no accident that Epshtein concludes that "essayism is a much more wide and powerful stream than any other philosophical or artistic streams $<\ldots>$ just because it does not represent 
the move of a cultural branch, but demonstrates a separate feature of the whole modern culture" (Epshtein, 1982).

The essayistic type of writing is an extremely wider phenomenon rather than the essay genre per se.

Taking a risk of being accused in termjuggling, we note that these two absolutely similar in the entire senses texts can involve two opposite types of writing, i.e. a classic and essayistic one.

Creating "Don Quixote", Miguel de Cervantes preserved being its writer, since actualizing his inner artistic demand, he, at the same time, wanted to communicate his thoughts and findings to other people; to improve his material status and maintain the relationship with the strong supporters.

Borges's Pierre Menard, who spend the years in hard working to re-write in word-for-word two and a half chapters of "Don Quixote", but in so that, it would be perceived as initially his own "Don Quixote", is not a writer, but an essayist.

Essayism is not a simple self-realization and self-identification of the artist within the process of writing (that is also peculiar to a traditional type of work). This is mainly an existential selfperformance of the author through the writing. A pioneer of essayistics, Montaigne, says: "My book is created by me in the same sense as I am created by this book. This should be a book integral with its author; a book which demonstrates my principle activity, integral part of my life, and not the one that have some specific, foreign aims as it usually is with other books" (Montaigne, 1979: 593).

Indeed, Gogol's Akaky Akakievich is also an example of essayist, who, rewriting absolutely alien and boring official papers, sees "some kind of his own, diverse and appealing world"; for whom "nothing exists $<\ldots>$ outside this rewriting"; and "if he looks at something, then he'll see only his accurate, calligraphically written lines, and unless, out of nowhere, a horse face lies on his shoulders and fills with a wind, only this time he notices that he is not in the middle of the line, but rather in the middle of the street (Gogol', 1938: 145-146).

This example, with all its conventions and grotesqueness, is interesting because it points out a significant feature of the essay, i.e. its inherent non-communicativeness. The original aim of any essayistic writing lies beyond its meaning. The document as a text that can be read, that can be highly important for someone, that can influence someone's fate, and the document as a deeply personal event in Akaky Bashmachkin's life have nothing in common. The essay escapes from the logos's jurisdiction. The meaning of the text, deriving from its sign nature and faced outward (to a potential recipient), and the meaning of the writing (for the scriptor themselves) are two parallel and in no way contiguous meanings. The confluence and diffusion are possible, but the closer and more frequent they are, the smaller essay and the bigger literature are.

From the three literature forms the essay most clearly anticipated by the lyrics initially oriented on the subject of creation and not of the reception process; on an inner event, and not on an outside one. However, the lyrics as well as any other literary phenomenon per se represent an objectification of it-self in the word. The most essential thing here is a verbal result: if there is nothing of that kind or if it does not prove to be successful, the act of creation in lyrics is considered as incomplete or cancelled. The essay is a life inside the letters. It is a verbal activity per se. The verbal result is its inevitable, but a side effect. In case, if it takes place in philosophical or aesthetical senses and is of someone's concern, than, rather, it will be good; it can even be evaluated as an indirect indicator of the inner content of the producing process. Still, it has little importance. 
The highest degree of essayism is a nonvoluntary writing just as reflexive and irresistible as blinking or sneezing, with the only difference that they are defined without any aesthetical message, while the essayism at its core is a revealing of the personal ordinary life not only within chronological, but also aesthetical dimensions.

That is why the essay's author does not impose anything upon anyone. They express something not with the intention to say, but due to their natural ability to articulate.

Thus, lowing down to a solely physiological body level, the aesthetics achieves the heights of a purely existential writing almost inaccessible for the traditional forms of literature.

In many senses the same function is performed by diaries, memoires and autobiographies. Still, there are two fundamental differences. The essay represents a direct and independent life action among other variety of forms the existence. The diary, autobiography, and memoires, to some degree, are considered as an attempt to fill our life with certain meaning outside an immediate process of existence. In other words, it is an opportunity to re-live one's life at the new level of reflection.

The diary and memoire writing are the conservation and meaning enrichment of already actualized process of existence (though it may involve a reflexive component).

The other difference lies in the fact that the diary sis understood as a soundly personal phenomenon; certain exceptions such as Lev Tolstoy's diary only support that rule. The memoires and autobiographies are traditionally intended for a large audience, but it consequently deprives them of that existential power peculiar to the diary: in this context, a personal event turns out to be a public one.

In comparison with these genres, the essay stands apart. The instinctive essence of the writing gives an opportunity for the intrapersonal event to be realized within the public sphere without loosing its private content.

To resume briefly: the essay, in comparison with the epitome, contains an active involvement into the existence through the author's writing, but not through the reader. The later, in turn, receives only a cold verbal "ash", but not that original existential "flame" for the sake of which, basically, the essay has been intended. The existention cannot be realized in the word a priori. Nevertheless, keeping inside the very essence of the existential creation, the essay, at the same time, becomes some sort of a guideline on "diving" which gives the reader hints on how they can enter the same process.

\section{Blog: the paradigm "breaking"}

The blog is considered to be generated from the same sources as the essayistics and the beginning of their histories mostly coincide. Still, as a separate form of literary creation, blog was recognized at the boundary between the 22th and $21^{\text {st }}$ centuries due to a universal spread of the Internet as well as to the appearance of special online services which allow keeping one's own "online diary" on a ready-made platform with sophisticated interface without any need in creation and administration over the site.

The word "blog" derives from the English "web log" that can be translated into Russian as «веб-журнал событий», «интернет-дневник», «онлайн-дневник». Still, despite the etymology, the blog is not considered as the diary per se. It is more accurate to say that it such notes which we make on the margins of our life.

The blog's format suggests a regular posting in a certain web-field (at the intervals from several times a day to once in several days) relatively small materials. Initially, blogs were purely of a verbal and text character, but soon, other types of the context have also been applied: thus, now we 
have photo-, audio- and video-blogs (it should be noted that the later are undergoing now the peak of their never-seen-before popularity and becoming a tough competitor for the entertaining TV).

Visual, audiovisual or audio-blogs, as a rule, differ by their mono-format: for example, in the video-feed we are not likely to find any static images or text elements. A "traditional" blog, a father of the whole modern blog-sphere, in contrary, is more heavily inclined towards a multi-format character: alongside with the text posts considered as its basis it also harmonically contains photos, de-motivators, videos and music which quite often are mixed with other types of materials and serve as certain emotion-markers called up to form a correct modality of perception of the main content or to express the blogger's state of mind. The developing "blurring of the textuality" is largely caused by the influence of the social networks especially that today that border between them and blogs is becoming more and more artificial: to sample, recently the Russian bloggers have in mass been migrating from the "Live Journal" to "Facebook" which is more intellectually suitable for them.

A particular note in the blog - a post (from the English - "to send a letter") - can have characteristics of any genre: there are no strict limits on this feature. It can be an aphorism, rhetorical question or exclamation, prosaic lyric miniature, anecdote, everyday or satiric sketch, philosophic item, journalistic proclamation, feuilleton, political analytics, literary or artistic analysis and etc. The "classic" blog leans on explicated text structures, though even here being influenced by the social networks we can find a progressive minimalization of the size (together with a simultaneous concentration of the meanings).

Similar to the essay, blog is also a genre beyond other genres. However, even in such logically paradoxical definition the term "genre" is understood in immeasurably narrow way for such a multi-dimensional phenomenon which we try to describe. Perhaps, it is more accurate to speak about the blog as about a certain integrative model which allow combining complete works and fragments related not only to different genres, but also to different sign systems within one and the same visual and temporal stream. Let's emphasize: to consider the blog as a cyclic structure, as a combination of traditional literary forms is, in our opinion, an illegal simplification. The cycle's content as a whole is irreducible to a simple sum of its components, but, at the same time, it is isomorphic to each of them, and its common function can be deduced from the functions operated by the components. The blog's operation lies in an absolutely different plane, rather than the functions of particular posts if we analyze each of them separately.

Initially and basically the blog represents the text. In the meantime, the blog hides its visual nature: its feed is a vivid and viewable realization of our life, which at any moment of time, can become movable and streaming just following the slight touches by our fingers and evolve both in a tiny space of the screen and in time as well.

It bears repeating that the blog is not a diary, though some forms of literature (particularly, in the $20^{\text {th }}$ century) traditionally called "diaries" stand very close to it (let's remember M.M. Prishvin). The diary originally represents a tool which gives an opportunity to fixate and reflect the tide of our life: the primary reflection is made inside the fixation of our experience; more detailed and sound one - in the terms of further accesses to the diaries. The diary development means somewhat of a meta-process in the relation to the primary existence. This is thinking over the life that we comprehend as something separate from the existence per se: as something that appears as a respond to it and, thus, that set against it. 
The blog in very rare cases performs in the function of "personal chronicle" peculiar to the diary, although it also has such opportunity. The blog can be reflectable, butrather in biological, than in philosophical sense: the same as elementary physiological stimulus induce some reflective body reactions, so the complex mental stimuli are perceived by our consciousness through the cognitive and verbal reactions. Blogging is one of the numerous aspects within the lively process; that is thinking about the genesis understood as its coherent and integral element.

The blog manages to shift a brand-new level in the quality, in comparison with the diary due to its interactivity which constitutes nearly its core feature.

The blog is not just a public phenomenon, but a pronouncedly social one. It requires a constant writer-and-reader communication as well as interaction with other bloggers (reposting and comments on other posts, respond to comments, posting as the reaction on other posts and comments).

Such blog created by a man who does not react on any other blogs can hardly be recognized as a blog. Such blog that stays uncommented does not represent a blog at all, but just a sequence of notes, essays and remarks posted in the web.

The notion of blogosphere by no coincidence springs up on the analogy of noosphere. It is not a simple set of separate blogs, but inherently interrelated space consisting of numerous interpenetrating lively "streams of consciousness" intertwisting with each other into an incredibly solid and semantically tense unity.

The blog is a vividly verbal materialization of R. Barthes's concept of the text (since Barthes's text is a phenomenon characterized by mental and not verbal basis) (Barthes, 1989). It has no author considered as a sole meaningand structure-forming actor, since its debatable nature neutralizes any claims to monopolize the senses, and such an open texture, in turn, together with interactivity - any pre-determination in the structure. It exists only in dynamics and cannot "freeze" once and forever, be transformed from the process into the object, i.e. into a closed with the book-covers work. Such metamorphose means death; it basically distinguishes the blog from both the essay and diary.

The cases of blog's transformations within the classic works are not rare. As a rule, they are represented by collections of essays, humoristic sketches or autobiographical epitomes. We remember Ye. Grishkovets's books "God ZhZhizni”, "Prodolzheniye ZhZhizni”, "151 Episod ZhZhizni”, "Ot ZhZhizni k ZhZhizni” (double sound "ZhZh" in the titles point out the blog-platform called "Zhivoy Zhurnal" (eng. - Life Journal)); O. Lukas's "Porebrik iz Bordyurnogo Kamnya", "Novy Porebrik iz Bordyurnogo Kamnya", "Porebrik Nanosit Otvetny Udar" and of many other bloggers.

In 2006 "Lulu Press", an American company specializing on publishing services for amateur-authors, founded an international "Lulu Blooker Prize" awarded the books based on such "net-journals". Despite of the project's ambitiousness, its title which refers to one of the most famous awards ("Booker") it lived only for two years. However, it's not surprising: originally initiated as an advertising campaign, it proved to be success in its function, after which the founders lost their interest. Still, it managed to enrich the vocabulary of literature and critics and name the whole class of phenomena: blooks now nominate the printed versions of the texts posted in blogs.

The blog's shift to the blook is a traditional and commercial tribute. Despite the fact that efficient ways to monetize the blogging have already been known, they also require endeavouring of the author. The book issue provides an opportunity to put the pressure of financial troubles and 
arrangements on the publishing house's personnel, to earn extra-money on already published texts and significantly expand the reader's audience and, finally, what is of no little interest, to get a valid right to be recognized as a writer.

It is notably that, following "Blooker", the Russian prize called "BlogBuster" (that did not last long time) was oriented mainly on blogs, rather than on blooks.

A "sudden" occurrence and no less sudden disappearance of the literary awards designed for the bloggers is symptomatic. On the one hand, a decade ago it became obvious that the blogs which represented a specific literary form could not be ignored. On the other - even in a decade - the blogosphere is still quite marginally in the contact with the sphere of traditional literature, what makes us to conclude that in the future each of them would also develop separately.

The blog possesses a full set of distinguishing features typical of so called network literature, or more precisely, of "netrature", as the net literary forms are commonly called, contrary to the traditional models of literature posted in the Internet. Among these characteristics the most important are hyper-textuality, interactivity, dynamism (procedurality) and multi-authorness (Andreev, 1998; Kuritsyn, 2001). Still, the blog does not demonstrate the literature, even the net one.

Without considering the problem on the netrature's essence and borders, we note that it can be divided into two large groups of phenomena. In both of them one actively uses new constructive possibilities which have become available only in the Internet. However, on the one hand, this toolkit is exploited to stretch the literature's borders, to expand additional levels in the framework of the current paradigm, and on the other - to go beyond its limits to elaborate verbal and creative, but not literary ones, forms.
Today, with a great deal of confidence we can say that the phenomena of the first group (the netrature per se) represent a dead end in the development of the verbal art. The hypertext novels, bouts-rime projects (like "Sad Raskhodyaschikhsya Khokku"), different experiments in the area of digital poetry and human-machine creation - all these seemed to be a daring step towards "unknown" that time, to something which promised awesome aesthetical breakthroughs and literary revolutions of exceptional scale. Ones, like the hypertext novel, have gone soon after its birth proving its inviability; others, like "Sad Raskhodyaschikhsya Khokku" are still developing and enhancing. Still, no revolutions - either global or even local ones - these projects did make by staying purely in the niche.

The second part of phenomena the gradual evolution of which results in the blogs and social networks has cardinally changed the landscape of the mordern literature.

It might seem that the blog delivers a Latin maxima "Nulla dies sine linea" well remembered from the period of Pliny the Elder and well known in the Russian variant by Yuriy Olesha $-\ll Н и д н я$ без строчки».

Still, the creative idea actualized by this aphorism has a strictly imperative nature: the artist must entirely be devoted to his duty which is the core meaning of his life. The blog is nonimperative, i.e. its development is influenced by not so much creative, but rather sociocommunicative impulse. It's based on a noncommittal chatting, on oneself verbalization within everyday interaction. The subject's existence inside the word turns out to be inseparable from the routine and organically interweaves with it. A constant "verbalization" of the ordinary life in its authentic, persistently nontransformed by the aesthetics forms becomes a creation. 
As often as not we are to face with a dogmatic statement that the blogs have nothing in relations with a true art, that they have not enriched the world with something like "War and Peace" or "Crime and Punishment", and that they are simply pulp-writers' whims.

Firstly, ninety percent of the literary art (both in traditional and non-traditional forms) are considered as graphomania. Within the long history, the literature has managed to create efficient mechanisms for self-filtration. The blogosphere has not had yet over almost the quarter-century period.

Secondly, due to a heavy "information pollution" the highly artistic items are definitely hard to be spotted, especially given that almost no one deliberately tried to find them. But they are. For example, Boris Akunin's blog which is always lost on the literary critics and studies, in our opinion, is a phenomenon much more important than his novels.

Thirdly, nothing similar to "War and Peace" or to "Crime and Punishment" the blogosphere cannot principally generate. That is why there is no reason in trying to formulate its aesthetic values and criteria of its aesthetic evaluation through mainly alien categories. Speaking about the phenomena, not similar, but equivalent to "War and Peace", so we are hardly to find any so soon.

\section{Conclusion}

Back in the end of $80^{\mathrm{s}}$ in the $20^{\text {th }}$ century, M.N. Epshtein with a truly genius farsightedness wrote: "The essayistic commitment to the union and apposition of different cultural layers replaced that centralizing tendency which previously related to the mythical consciousness. The synthetism of essays means humanistic and personal reconstruction of that syncretism which in ancient times was grounded on the integrity of the cave-man community and that had an out-personal, cosmic or theistic orientation. The essay's paradox lies in the fact that through its reflective and individualistic nature, it stands against the myth and any other mythologism, not in the same way as a separate part resists to the whole, but as if a newly formed whole stands against the initial one (Epshtein, 1988: 349).

The quarter-century later, one may state that these characteristics relate not so much to the essay-genre, but rather to the new global literary paradigm which is now being actively formed and which may well cover both essayistic and other similar types of writing as well.

From the ancestress it differs by the intention to withdraw an irresistible conflict between the genesis-in-art and genesis-in-reality.

The comparison of non-generic literary forms, such as epitome and essay, allows concluding on two initial stages of the alternative paradigm development: the text considered as an instrument of the passive participation of the subject in the lively out-personal existence (epitome) and of the active existential selfrealization through the writing (essay). The third stage corresponds to the blogosphere finding itself on the border between the literature and non-literature. The blog analyzed as a specific form of literature involves active and constant continuation of the subject's personal and social existence through the writing (in this way, they, by turns, act both as the author and the recipient). By eliminating the opposition "art/reality", the essayistic writing shies away from the other, not less fundamental antinomy "existential/social" which, in turns, turns out to be integrated into the blogosphere.

Thus, with a new degree of completeness the blog reveals, but by no means, finishes those global cultural processes which have brought the epitomistics and essayistics to the light.

We have touched only some aspects of the huge and extremely sophisticated problem. 
A slow process of the paradigms revolution accompanied by tectonic shifts in the stylistic and sign layers, by the appearance of numerous interparadigm phenomena which obstructing the analysis, carries simultaneously across all the cultural front lines.

One and the same tendencies may differently (sometimes even up to a complete non-identification) emerge both in the essayistics, blogosphere, social networks and in the works by the performance artists, such as Petr Pavlensky or Boryany Rossy. Only a comprehensive study of these absolutely mixed, at a glance, phenomena related to almost faraway spheres of the culture can solve the problem on its further development.

\section{References}

Andreev, A. (1998). SETERAtura kak ee NET: ot estetiki kheiana do kletochnogo avtomata - $i$ obratno [Web Literature that There is No: From the Aesthetics of the Heian to the Cellular Automata and Back]. Available at: http://www.netslova.ru/andreev/setnet/ 03.02 .1998 (accessed November 28, 2016).

Aristov, V. (2010). Esse: ontologicheskie ustanovki i formalnye granitsy [Essay: Ontological Assumptions and Formal Border], In Novoe literaturnoe obozrenie [New Literary Review], 104. Available at: http://magazines.russ.ru/nlo/2010/104/ar19.html

Barthes, R. (1989). Izbrannye raboty: semiotika: poetika [Selected Works: Semiotics: Poetics]. Moscow, Progress.

Epshtein, M.N. (1982). Esse ob esse [Essay about Essay]. Available at: http://old.russ.ru/antolog/ intelnet/es_esse.html (accessed 28 November, 2016).

Epshtein, M.N. (1987). Rod literaturnyi [Literary Genre], In Literaturny entsiklopedicheskii slovar [Literary Encyclopedia]. Moscow, Sovetskaia Entsiklopediia.

Epshtein, M.N. (1988). Paradoksy novizny: o literaturnom razvitii XIX - XX vekov [Paradoxes of Novelty. About the Literary Development in the $19^{\text {th }}-20^{\text {th }}$ Centuries]. Moscow, Sovetskii Pisatel.

Gogol', N.V. (1938). Polnoe Sobranie Sochinenii, Tom III [Full Collection of Writings, Volume III]. Moscow, Leningrad, Izdatel'stvo AN SSSR.

Khalizev, V.E. (1999). Teoriia literatury [Literary Theory]. Moscow, Vysshaia shkola.

Gordeeva, E.Iu. (2001). Ocherk [Epitome], In Literaturnaia entsiklopediia Terminov i Poniatii [Literary Encyclopedia of Terms and Concepts]. Moscow, NPK Intelvak.

Kuritsyn, V. (2001). Son o seti [Dream about the Web]. Available at: http://www.netslova.ru/ teoriya/son.html (accessed November 28, 2016).

Montaigne, M. (1979). Opyty, knigi pervaia i vtoraia [Essays, the First and Second Books]. Moscow, Nauka.

Murav'ev, V.S. (2001). Esse [Essay], In Literaturnaia entsiklopediia terminov i poniatii [Literary Encyclopedia of Terms and Concepts]. Moscow, NPK Intelvak.

Otvety Mail.ru [Answers on Mail.ru] (2010). Available at: https://otvet.mail.ru/question/33099016 (accessed November 28, 2016).

Tamarchenko, N.D. (2001). Rod literaturnyi [Literary Genre], In Literaturnaia entsiklopediia terminov i poniatii [Literary Encyclopedia of Terms and Concepts]. Moscow, NPK Intelvak.

Zverev, A.M. (2001). Potok soznaniia [Stream of Consciousness], In Literaturnaia entsiklopediia terminov i poniatii [Literary Encyclopedia of Terms and Concepts]. Moscow, NPK Intelvak. 


\section{Генезис внеродовых форм в литературе \\ (очерк - эссе - блог)}

\section{С.А. Демченков}

Омский государственный университет

им. Ф.М. Достоевского

Россия, 644077, Омск, пр. Мира, 55а

Статья посвящена проблеме становления внеродовых форм в литературе. В работе показано, что их несоотносимость со сложивщейся системой литературных родов обусловлена их особой онтологической природой. Очерк, эссе и блог отмечают три последовательных этапа формирования новой парадигмы словесного творчества, которая стремится к преодолению антиномий «искусство и действительность», «экзистенџиильное и сочиильное», задающих точки отсчёта в системе координат традиционной словесности. Новизна использованного в статье методологического подхода заключается в том, что спечифика внеродовых форм рассматривается в аспекте не только их эстетических характеристик, он и их экзистенциальной функиии.

Ключевые слова: литературный род, внеродовые литературные формы, очерк, эссе, эссеизм, блог, дневник, экзистенция.

Научная специальность: 10.00.00 - филологические науки. 